\title{
Działania na rzecz ochrony praw osób z niepełnosprawnością - propozycje zmian
}

Celem tego artykułu jest zaprezentowanie aktów prawa międzynarodowego (o różnym charakterze i mocy obowiązującej, z podziałem na akty prawne ogólne i szczególne), wydawanych przez Zgromadzenie Ogólne Narodów Zjednoczonych i Unię Europejską dotyczących praw osób z niepełnosprawnością, ich uporządkowanie, co wydaje się zasadne ze względu na ich dużą różnorodność. Akty prawne do obszarów szczególnej troski zaliczają: ochronę zdrowia, usługi medyczne, rehabilitację, zatrudnienie oraz edukację i w tych zakresach przewidują zabezpieczenie potrzeb osób niepełnosprawnych, tak by mogli funkcjonować i pełnić role społeczne, a także wskazują instrumenty egzekwowania tych praw. Celem artykułu jest też analiza sytuacji i problemów związanych z brakiem lub ograniczeniem możliwości korzystania z uprawnień $\mathrm{w}$ różnych sferach życia społecznego przez osoby z niepełnosprawnością w Polsce, wskazanych w dokumentach - Informacjach o działalności Rzecznika Praw Obywatelskich i Rzecznika Praw Dziecka w 2015 r. Ważną część analizy stanowią propozycje zmian przepisów prawa krajowego w różnych dziedzinach prawa: cywilnego, rodzinnego i opiekuńczego, socjalnego.

Słowa kluczowe: prawa, akty prawne, ochrona, osoby z niepełnosprawnością, zmiany, działania

\section{Activities for protection rights of the people with disabilities - propositions of changes}

Summary: An aim of the paper is presentation of the international legal acts (with different character and effective power, as well as with discrimination for general and particular acts), made by General Assembly of United Nations Organization and European Union related to the rights of the people with disability. A goal of the paper is also presentation of the structure of legal acts what is justified because of the different character of particular documents. In the legal acts there is placed special interest related to the following issues: health protection, medical service, rehabilitation, employment and education, into these spheres legal acts especially provide protection of the needs of people with disabilities, to help them functioning in the social roles, in the legal acts there also indicated legal tools of exercising and enforcing specific rights. The aim of the paper is also analysis of the situations and problems connected with the lack of possibilities related to the taking advantage of the specific rights in the different spheres of life of the people with disabilities in Poland. This data are presented in the documents: Information related to the Activity of Commissioner for Human Rights and Information related to the Activity Commissioner for 
Childrens' Rights in 2015. Important part of the article are propositions related to changes of Polish legal acts in relations to the civil law, family and care law and social law.

Keywords: rights, legal acts, protection, people with disabilities, changes, activities

\section{Wprowadzenie}

Celem artykułu jest uporządkowanie aktów prawa międzynarodowego dotyczących praw osób z niepełnosprawnościami i wskazanie tych, które miały znaczenie dla polskiego porządku prawnego, ale także analiza problemów związanych z brakiem lub ograniczeniem możliwości korzystania z uprawnień (gwarantowanych w przepisach prawa) przez osoby z niepełnosprawnością oraz analiza propozycji dokonania zmian $\mathrm{w}$ przepisach prawa krajowego w kierunku równego ich traktowania i prawa antydyskryminacyjnego (z uwzględnieniem tych zaproponowanych przez Rzecznika Praw Obywatelskich i Rzecznika Praw Dziecka).

Prawami człowieka zwykło się nazywać określone prawa i wolności przysługujące każdej jednostce ludzkiej z tego właśnie tytułu, że jest ona człowiekiem. Są to prawa i wolności, które przysługują niezależnie od postanowień władzy państwowej, nie są one przez tę władzę nadawane. Mają swoje źródło w przyrodzonej godności człowieka [Andrzejewski 1999: 140-141].

Prawa osób niepełnosprawnych są określone w prawie międzynarodowym, które porusza problemy ochrony i pomocy osobom niepełnosprawnym. Prawo międzynarodowe określa powszechny standard ochrony praw człowieka, wspólny dla państw zróżnicowanych pod względem tradycji kulturowych i ma wpływ na rozwiązania krajowe (w różnym zakresie, zależnie od obowiązującej mocy aktu prawnego). W międzynarodowych aktach prawnych dotyczących praw i wolności człowieka zwraca się uwagę na przyrodzoną godność, równość i niezbędne prawa ",każdego człowieka”, „wszystkich członków rodziny ludzkiej”.

Równość ${ }^{1}$, obok godności i wolności, to przewodnie zasady, które określają status jednostki w państwie [Zima-Parjaszewska 2012, s. 16].

Niepełnosprawność jako cecha chroniona przez prawo pojawiła się $\mathrm{w}$ wielu dokumentach międzynarodowych.

$\overline{1}$ Art. 5 Konwencji o prawach osób niepełnosprawnych stanowi, iż „wszyscy ludzie są równi wobec prawa i są uprawnieni, bez jakiejkolwiek dyskryminacji, do jednakowej ochrony prawnej i jednakowych korzyści wynikających z prawa". 
Wykaz międzynarodowych aktów prawnych służących ochronie praw osób z niepełnosprawnością

Wykaz dokumentów międzynarodowych ujęto według kryterium podmiotu/ organu, który akt prawny uchwalił oraz kryterium zakresu jego mocy obowiązującej. Rozwiązania sprzyjające ochronie praw osób z niepełnosprawnością przyjęto $w$ wielu aktach prawa międzynarodowego, m.in. w dokumentach ogólnych i szczególnych [Jankowska, www.pfron.org.pl, dostęp: 22.02.2017]:

1) ogólnych przyjętych przez Zgromadzenie Ogólne Narodów Zjednoczonych, takich jak:

- Powszechna Deklaracja Praw Człowieka przyjęta 10.12.1948 r. przez Zgromadzenie Ogólne Narodów Zjednoczonych w Paryżu [www.unic.un.org.pl; prawa_człowieka, dostęp: 22.02.2017],

- Międzynarodowy Pakt Praw Obywatelskich i Politycznych uchwalony 16.12.1966 r.; Międzynarodowy Pakt Praw Gospodarczych, Społecznych i Kulturalnych z 1966 r. [www.ms.gov.pl/pl/prawa-człowieka, dostęp: 22.02.2017];

2) szczególnych przyjętych przez Zgromadzenie Ogólne Narodów Zjednoczonych, takich jak [Piasecki, Stępniak 2002]:

- Deklaracja Praw Osób z Upośledzeniem Umysłowym z 1971 r.,

- Deklaracja Praw Osób Niepełnosprawnych z 1975 r.,

- Deklaracja Praw Osób Głuchych i Niewidomych z 1979 r.,

- Rezolucja Zgromadzenia Ogólnego z 1976 r., ustanawiająca rok 1981 Międzynarodowym Rokiem Osób Niepełnosprawnych,

- Światowy Program Działań na rzecz Osób Niepełnosprawnych przyjęty na mocy rezolucji Zgromadzenia Ogólnego NZ z 3 grudnia 1982 r.,

- Zasady Tallińskie przyjęte w 1989 r;

- Zasady Ochrony Osób Cierpiących na Choroby Psychiczne oraz Poprawy Opieki Zdrowotnej w tym Zakresie przyjęte w 1991 r.,

- Standardowe Zasady Wyrównywania Szans Osób Niepełnosprawnych przyjęte w $1993 \mathrm{r}$.,

- Podstawowe Standardowe Zasady Dotyczące Wyrównania Możliwości Rozwojowych Dla Osób Niepełnosprawnych przyjęte 20.12.1996 r.,

- Konwencja Praw Osób Niepełnosprawnych z 13 grudnia 2006 r.

W dokumentach europejskich - aktach o charakterze ogólnym, takich jak:

- Europejska Konwencja o Ochronie Praw Człowieka i Podstawowych Wolności przyjęta pierwotnie w 1950 r. przez kraje Rady Europy,

- Europejska Karta Społeczna uchwalona w 1961 r.,

- Karta Praw Podstawowych Unii Europejskiej z 2000 r. 
W dokumentach Unii Europejskiej (www.niepelnosprawni.gov.pl/dokumentyorganizacji-narodow-zj; dostęp: 10.02.2011], takich jak:

1) Traktaty: Amsterdamski, którego art. 13. zawiera przepis zakazujący dyskryminacji, również ze względu na niepełnosprawność; Lizboński, do którego została włączona omówiona wyżej Karta Praw Podstawowych Unii Europejskiej.

2) Dyrektywy europejskie:

- Dyrektywa Rady z dnia 27 listopada 2000 r. (2000/78/WE), ustanawiająca ogólne ramy na rzecz równego traktowania w zakresie zatrudnienia i pracy.

3) Rozporządzenia podlegające bezpośredniemu stosowaniu $w$ państwach członkowskich:

- Rozporządzenie Komisji z dnia 6 sierpnia 2008 r. (2008/800 WE), uznające niektóre rodzaje pomocy za zgodne ze wspólnym rynkiem w zastosowaniu art. 87 i 88 Traktatu.

4) Decyzje - akty prawne o charakterze indywidualnym, skierowane do państw lub do podmiotów prawa:

- Decyzja Rady z dnia 27 listopada 2000 r. Ustanawiająca Wspólnotowy Program Działania w Zakresie Zwalczania Dyskryminacji;

- Decyzja Rady z dnia 3 grudnia 2001 r. w sprawie Europejskiego Roku Osób Niepełnosprawnych 2003;

- Decyzja Parlamentu Europejskiego i Rady z dnia 7 grudnia 2001 r. ustanawiająca program działań Wspólnoty wspierający współpracę między Państwami Członkowskimi w celu zwalczania wyłączenia społecznego;

- Decyzja Rady z dnia 12 lipca 2005 r. w sprawie wytycznych dla polityk zatrudnienia państw członkowskich;

- Decyzja Komisji Europejskiej z 27 czerwca 2007 w sprawie wsparcia dla zakładów aktywności zawodowej.

5) Zalecenia:

- Zalecenie Rady nr 376 z 1998 r. dotyczące Kart Parkingowych dla Osób Niepełnosprawnych;

- Zalecenie nr 1592 z 2003 r. Zgromadzenia Parlamentarnego Rady Europy „W kierunku społecznego włączenia osób niepełnosprawnych do życia społecznego";

- Zalecenia Komitetu Ministrów dla państw członkowskich. Plan działań Rady Europy w celu promocji praw i pełnego uczestnictwa osób niepełnosprawnych w społeczeństwie: podnoszenie jakości życia osób niepełnosprawnych w Europie 2006-2015.

6) Uchwały [www.niepelnosprawni.gov.pl/dokumenty-organizacji-narodow-zj/ konwencja-o-prawach, dostęp: 10.02.2011]:

- Uchwała Rady i Przedstawicieli Rządów Państw Członkowskich, spotykających się w ramach Rady z 20 grudnia 1996 r. nt. równych szans dla osób z niepełnosprawnością; 
- Uchwała Rady z 17 czerwca 1999 r. w sprawie Równych Szans w Zatrudnieniu dla Osób Niepełnosprawnych (1999/C 186/02).

7) Deklaracje:

- Deklaracja Madrycka, podjęta na Europejskim Kongresie na rzecz Osób Niepełnosprawnych (20-24 marca 2002 r.): „Brak dyskryminacji plus działania pozytywne dają $w$ efekcie społeczne włączenie".

8) Rezolucja:

- Rezolucja Rady Unii Europejskiej i przedstawicieli rządów państw członkowskich, zebranych w Radzie z dnia 17 marca 2008 r. w sprawie sytuacji osób niepełnosprawnych w Unii Europejskiej (2008/C75/01).

9) Programy - dokumenty przyjmowane przez Radę.

Jak wynika z przedstawionego zestawienia, akty prawa międzynarodowego wydane przez różne uprawnione podmioty/organy, mają różny charakter i moc obowiązującą. Do obszarów szczególnej troski dokumenty międzynarodowe zaliczają: ochronę zdrowia, usługi medyczne, rehabilitację, zatrudnienie oraz edukację, i w tych zakresach przewidują zabezpieczenie potrzeb osób niepełnosprawnych, tak by mogli funkcjonować i pełnić role społeczne. Przepisy prawa międzynarodowego zawarte $\mathrm{w}$ dokumentach ogólnych zwracają uwagę na wszystkie kategorie osób niepełnosprawnych, w szczególności jednak na dzieci i kobiety niepełnosprawne, które są $\mathrm{w}$ większym stopniu niż pozostałe osoby niepełnosprawne narażone są na ryzyko wykluczenia i marginalizację społeczną. Prawa osób niepełnosprawnych $w$ dokumentach międzynarodowych określono precyzyjnie, a także zwrócono uwagę na poszanowanie ich godności i zapewnienie równych praw.

W systemie ochrony praw osób niepełnosprawnych podstawową rolę odgrywa Konwencja o prawach osób niepełnosprawnych przyjęta 13 grudnia 2006 r. na mocy rezolucji nr 61(106) przez Zgromadzenie Ogólne Narodów Zjednoczonych [www.ms.gov.pl/pl/ prawa-człowieka, dostęp: 22.02.2017]2. Celem Konwencji jest zapewnienie pełnego i równego korzystania ze wszystkich praw człowieka i podstawowych wolności przez wszystkie osoby z niepełnosprawnością. W Konwencji zwrócono uwagę na zapewnienie równości i niedyskryminacji osób niepełnosprawnych. Szczególnej ochrony w związku z trudną sytuacją i ryzykiem wykluczenia społecznego wymagają kobiety i dzieci niepełnosprawne, w związku z tym zwraca się uwagę na konieczność podejmowania wszelkich środków w celu zapewnienia im korzystania z praw człowieka i podstawowych wolności w najlepszym ich interesie. W Konwencji potwierdza się prawo osób niepełnosprawnych do

2 Polska podpisała Konwencję w dniu 30.03.207 r., Sejm RP uchwalił ustawę ratyfikacyjną 15.06.2012 r., a uroczysta ratyfikacja Konwencji przez Prezydenta RP miała miejsce 6.09.2012 r. Konwencja wiąże Polskę w stosunkach wewnętrznych i zewnętrznych od dnia 25.10.2012 r. po opublikowaniu jej w języku polskim w Dz. U. z 2012 r., poz. 1169. 
uznania ich podmiotowości prawnej oraz zwraca uwagę na zapewnienie środków potrzebnych przy wykonywaniu zdolności prawnej. Konwencja stanowi próbę odejścia w zakresie zdolności do czynności prawnych osób z niepełnosprawnością od systemu zastępczego podejmowania decyzji i wprowadzenia systemu wspieranego podejmowania decyzji. Konwencja w art. 12, pkt 3 wskazuje, że środki związane z korzystaniem ze zdolności do czynności prawnych mają obejmować odpowiednie i skuteczne zabezpieczenia w celu zapobiegania nadużyciom, zgodnie z międzynarodowym prawem praw człowieka. Konwencja stawia warunki by środki wspierające osobę z niepełnosprawnością przy korzystaniu ze zdolności do czynności prawnych były uznane za realizację art. 12. Środki te powinny: respektować prawa, wolę i preferencje osoby z niepełnosprawnością, być wolne od konfliktu interesów i bezprawnych nacisków, być proporcjonalne i dostosowane do sytuacji danej osoby, być stosowane przez możliwie najkrótszy czas, powinny podlegać stałemu przeglądowi przez właściwe, niezależne i bezstronne władze lub organ sądowy. Zabezpieczenia powinny być proporcjonalne do stopnia, w jakim środki wpływają na prawa i interesy danej osoby [Zima-Parjaszewska 2012: 19]. Konwencja przewiduje podjęcie wszelkich środków społecznych, administracyjnych, ustawodawczych w celu zapewnienia niepełnosprawnym ochrony w domu i poza nim przed wszelkimi formami wykorzystywania, przemocy i nadużyć, z uwzględnieniem aspektów związanych z płcią. Konwencja zobowiązuje Państwa Strony do podjęcia przez stosowne środki legislacyjne, administracyjne i społeczne skutecznych działań w celu poprawy warunków życia osób niepełnosprawnych.

\section{Propozycje zmian polskich przepisów prawnych dotyczących ochrony praw osób z niepełnosprawnością}

Dla poszanowania praw, przyznanych formalnie osobom z niepełnosprawnością w licznych aktach prawa międzynarodowego, zasadnicze znaczenie ma diagnoza i monitorowanie przestrzegania tych praw.

$Z$ analizy obowiązujących w Polsce przepisów prawnych ${ }^{3}$ wynika, iż nie są one w stanie zapobiec faktycznej dyskryminacji, zauważalnej przy edukacji osób

\footnotetext{
Zasada równego traktowania osób z niepełnosprawnościami jest przewidziana w wielu aktach prawnych, m.in.: Ustawa z 23.04.1964 r. - kodeks cywilny, ustawa z 17.11.1964 r. - kodeks postępowania cywilnego, ustawa z 26.04.1974 r. - kodeks pracy, ustawa z 20.04.2004 r. o promocji zatrudnienia i instytucjach rynku pracy, ustawa z 7.09.1991r. o systemie oświaty, ustawa z 27.08.1997r. o rehabilitacji zawodowej i społecznej oraz zatrudnianiu osób niepełnosprawnych, ustawa z12.03.2004 r. o pomocy społecznej, ustawa z 13.10.1998 r. o systemie ubezpieczeń społecznych, ustawa z 3.12.2010 r. o wdrożeniu niektórych przepisów Unii Europejskiej w zakresie równego traktowania (Dz. U. z 2010 r. Nr 254, poz. 1700), ustawa z 5.01.2011 r. - kodeks wyborczy, i inne.
} 
z niepełnosprawnością, ich zatrudnianiu, zabezpieczaniu społecznym, ich konkurencyjności na rynku pracy, a także korzystaniu z podstawowych praw i wolności obywatelskich, takich jak np. prawa wyborcze. Osoby niepełnosprawne mają zasadnicze trudności w uczestniczeniu w życiu publicznym, w korzystaniu z dóbr kultury, w dostępie do komunikacji, w dostępie do przysługujących im praw $\mathrm{w}$ różnych sferach życia społecznego.

Propozycje zmian w krajowych przepisach prawnych dotyczą następujących kwestii:

1. Zmiany wymaga system opieki rodzinnej nad osobami z niepełnosprawnością, m.in. chodzi o jednakowe, równe traktowanie opiekunów dorosłych osób $\mathrm{z}$ niepełnosprawnością, niezależnie od momentu powstania niepełnosprawności osoby wymagającej opieki członka rodziny.

2. Powrót do założenia, że $\mathrm{w}$ sytuacji rezygnacji z zatrudnienia jednocześnie matki i ojca w celu sprawowania opieki nad wymagającymi jej, różnymi niepełnosprawnymi, dziećmi, każdy z rodziców może otrzymać świadczenie pielęgnacyjne.

3. Usunięcie ograniczeń w dostępie do świadczeń opiekuńczych przez wprowadzenie zasady wyboru korzystniejszego świadczenia w przypadku zbiegu prawa do świadczenia pielęgnacyjnego oraz do emerytury (w szczególności wcześniejszej emerytury z tytułu opieki nad niepełnosprawnym dzieckiem) lub renty, a także zapewnienie dostępu do świadczeń z tytułu bezrobocia i do świadczenia przedemerytalnego opiekunom tracącym prawo do świadczenia po śmierci podopiecznej osoby niepełnosprawnej.

4. Usunięcie stanu dyskryminacji ubezwłasnowolnionych osób z niepełnosprawnością, którzy nie mają praw politycznych (pozbawione są praw wyborczych). W związku z tym wprowadzenie do kodeksu wyborczego formalnej definicji (a nie faktycznej) wyborcy z niepełnosprawnościami, co nie będzie ograniczało grupy osób, które będą mogły skorzystać z udogodnień/uprawnień tam przewidzianych.

5. Wpisanie w zdecydowany sposób (expressis verbis) zasady równego traktowania osób z niepełnosprawnościami do ustawodawstwa z zakresu zabezpieczenia społecznego, ochrony i opieki zdrowotnej, oświaty, szkolnictwa wyższego.

6. Uregulowanie kwestii zdolności prawnej i zdolności do czynności prawnej osób z niepełnosprawnością intelektualną.

Projektowana zmiana przyjmuje zasadę pełnej zdolności do czynności prawnych osoby dorosłej, a jako wyjątki możliwości ograniczenia korzystania z niej, jeżeli jest to konieczne ze względu na stan osoby dotkniętej niepełnosprawnością. Odchodzi się od sytuacji, w której osoba zostaje pozbawiona zdolności do czynności prawnych „w zakresie określonym w sposób abstrakcyjny i luźno tylko powiązany ze stanem psychicznym takiej osoby" [Pudzianowska 2014: 391-411]. 
Projekt przewiduje m.in. zmianę funkcji opieki i relacji między opieką a zdolnością do czynności prawnych - opieka ma być ustanawiana dla pomocy w prowadzeniu spraw przez osobę z niepełnosprawnością, a zakres obowiązków i kompetencji opiekuna ma być zależny od stanu psychicznego podopiecznego, przede wszystkim może obejmować: osobisty kontakt, wsparcie, asystencję, reprezentację tylko wtedy gdy to jest niezbędne.

Formy proponowanej opieki są zróżnicowane, a decyzję w tej sprawie podejmowałby sąd:

- opieka asystencyjna: udzielanie wsparcia $\mathrm{w}$ podejmowaniu decyzji przez opiekuna, osoba ma pełną zdolność do czynności prawnych;

- opieka z reprezentacją równoległą: osoba ma pełną zdolność, a opiekun jest upoważniony do reprezentowania podopiecznego w oznaczonym zakresie:

- opieka z kompetencją do współdecydowania, polegająca na zastrzeżeniu zgody lub potwierdzenia opiekuna dla ważności oznaczonych rodzajowo czynności;

- opieka połączona z umocowaniem do wyłącznego zastępstwa, w której upoważnienie do podejmowania czynności prawnych miałby w zakresie określonym w orzeczeniu opiekun [Ibidem, s. 400-401].

Zakres działania ma być zróżnicowany, od zapewnienia współudziału opiekuna $\mathrm{w}$ podejmowaniu decyzji przez osobę z zaburzeniami psychicznymi lub intelektualnymi, polegającym na doradztwie, aż do zastąpienia osoby podlegającej opiece $w$ dokonywaniu czynności prawnych przez opiekuna i pozbawienia tej osoby samodzielnego działania w tej sferze.

Jak twierdzi M. Zima-Parjaszewska, „Dalej pozostajemy w opiece, opieka nie ma nic wspólnego ze wsparciem, kiedy pozwala się, by dana osoba sama inicjowała działania. Według Konwencji o prawach osób niepełnosprawnych nie chodzi tylko o zabezpieczenie osoby, Konwencja wyznacza żądanie znalezienia form, które pomogą korzystać ze zdolności do czynności prawnych. W propozycjach zniknęła instytucja kuratora sądowego, który jest dobrym punktem wyjścia do szukania form wspierania osoby z niepełnosprawnością w konkretnej sytuacji" [(http://www.niepelnosprawni.pl, dostęp: 26.09. 2017].

Orzekając o opiece sąd brałby pod uwagę stan psychiczny osoby, w której sprawie orzeka (przesłanka medyczna), potrzebę ingerencji (przesłanka społeczna), kompetencje opiekuna.

$\mathrm{W}$ związku z proponowanymi zmianami niezbędne jest usunięcie obowiązujących przepisów dotyczących ubezwłasnowolnienia.

Zwrócono uwagę na nową instytucję (zapewniającą autonomię) tzw. pełnomocnictwo opiekuńcze, sens której polega na tym, że osoba dorosła i sprawna psychicznie może ustanowić pełnomocnika, który byłby upoważniony do dokonywania w imieniu mocodawcy określonych czynności, w tym także o charakterze osobistym, gdyby mocodawca doznał w przyszłości zaburzeń psychicznych. 
Są inne propozycje, np. wprowadzenie instytucji asysty i asystenta prawnego [Zima-Parjaszewska 2012: 25].

Istnieje konieczność zastąpienia modelu zastępczego (Rybski 2014) podejmowania decyzji modelem wspieranego podejmowania decyzji, który ma zapewniać poszanowanie praw, woli i preferencji osób z niepełnosprawnościami, jednocześnie ochronę przed nadużyciami, konfliktem interesów i nieuzasadnionym wpływem osób trzecich.

Model zastępczego podejmowania decyzji zakłada, że przedstawiciel prawny, opiekun, kurator uzyskał od sądu prawo do podejmowania decyzji w imieniu i na rzecz jednostki bez konieczności wykazywania, iż te decyzje są w najlepszym interesie osoby zainteresowanej lub zgodne z jej życzeniami. Model wspomaganego podejmowania decyzji zakłada wsparcie przez osobę wspomagającą, które umożliwia osobie z niepełnosprawnością podjęcie oraz zakomunikowanie decyzji w odniesieniu do spraw osobistych i/lub prawnych. Domniemanie będzie działać na korzyść osoby z niepełnosprawnością, której będzie dotyczyć podjęta decyzja. Osoba wspierająca omawia zagadnienia, gdy jest to konieczne oraz rozpoznaje sygnały i preferencje komunikowane ze strony osoby zainteresowanej, która podejmuje decyzję. Osoba wspierająca powinna umożliwić osobie z niepełnosprawnością korzystanie ze swoich uprawnień w najszerszym, możliwym zakresie, odpowiednio do jej życzeń lub do jej najlepszego interesu.

7. Usunięcie z kodeksu cywilnego ${ }^{4}$ budzących wątpliwości zapisów dotyczących ubezwłasnowolnienia [Pudzianowska 2014: 391-411]: związanych z pejoratywnym określeniem kręgu podmiotów, wobec których można orzec ubezwłasnowolnienie, związanych z ustaleniem „niemożności kierowania swoim postępowaniem" oraz "potrzeby pomocy w prowadzeniu swoich spraw”. Ustalenie, że jednostka nie jest w stanie kierować swoim postępowaniem, powinno obejmować analizę procesów poznawczych, stanu emocjonalnego, dojrzałości społecznej, zdolności rozumienia sensu działania, przewidywania skutków, motywacji, to w praktyce oznacza diagnozę konkretnych zaburzeń

$\overline{4}$ M. Zima-Parjaszewska [2012: 25] jest zdania, iż Polska powinna uchylić przepisy kodeksu cywilnego dotyczące ubezwłasnowolnienia i wprowadzić różnorodne formy prawnego wsparcia zgodnie z modelem wspieranego podejmowania decyzji, na kształt instytucji kuratora dla osoby niepełnosprawnej z art. 183 k.r.o. Formy te powinny być oparte na poszanowaniu autonomii i samodzielności osób potrzebujących wsparcia oraz nie powinny w sposób automatyczny ingerować w zdolność do czynności prawnych. Autorka twierdzi, iż ustawodawstwo powinno wyraźnie oddzielać kwestię prawnego wsparcia, tj. wsparcia w podejmowaniu czynności prawnych, od pomocy w codziennych czynnościach faktycznych. Formy prawnego wsparcia powinny być orzekane na określony czas, ze wskazaniem zakresu spraw, których dotyczą. Art. 183 § 1: Dla osoby niepełnosprawnej ustanawia się kuratora, jeżeli osoba potrzebuje pomocy do prowadzenia wszelkich spraw albo spraw określonego rodzaju lub do załatwienia poszczególnej sprawy. Zakres obowiązków i uprawnień kuratora określa sąd opiekuńczy. § 2: Kuratelę uchyla się na żądanie osoby niepełnosprawnej, dla której była ustanowiona" - ustawa z 25.02.1964 r. - kodeks rodzinny i opiekuńczy (Dz. U. z 2017 r., poz. 682). 
psychicznych. Konieczne jest poznanie nie tylko zachowania tej osoby, ale także zakresu spraw wymagających jej decyzji.

8. Włączenie osób ubezwłasnowolnionych do kręgu podmiotów uprawnionych do wszczęcia postępowania o uchylenie lub zmianę ubezwłasnowolnienia, co zasygnalizował TK w wyroku z 7.03.2007 r., Sygnatura K 28/05, [www.otk.trybunal.gov.pl/orzeczenia/otk.htm, dostęp: 10.02.2017].

9. Wpisanie prawa ubezwłasnowolnionych osób z niepełnosprawnością intelektualną (w imieniu których działa opiekun prawny) do zakwestionowania orzeczenia sądu opiekuńczego wyrażającego zgodę na umieszczenie tej osoby w domu pomocy społecznej, lub prawa tej osoby do wystąpienia o zmianę orzeczenia sądowego, $\mathrm{w}$ razie zmiany okoliczności (np. poprawy stanu zdrowia, możliwości skorzystania z opieki innej osoby).

10. Dokonanie zmian w systemie orzekania o niepełnosprawności dla różnych celów, a mianowicie, po spełnieniu warunków przewidzianych w ustawie o emeryturach i rentach z Funduszu Ubezpieczeń Społecznych, mogłyby się osoby niepełnosprawne ubiegać o przyznanie świadczenia, takiego jak renta z tytułu niezdolności do pracy.

11. Wyraźne uwzględnienie $\mathrm{w}$ obowiązujących progach dochodowych uprawniających do ubiegania się o świadczenia z pomocy społecznej specjalnych potrzeb osób z niepełnosprawnościami

12. Dookreślenie i poszerzenie zakresu zadań zlecanych fundacjom i organizacjom pozarządowym z zakresu rehabilitacji zawodowej i społecznej osób niepełnosprawnych.

13. Wprowadzenie prawa do złożenia przez osoby legitymujące się orzeczeniem o zaliczeniu do jednej z grup inwalidzkich odwołania od orzeczenia w przedmiocie wskazań do ulg i uprawnień.

14. Dokonanie zmian w ustawie o ochronie praw lokatorów i mieszkaniowych zasobach gminy i zmian w kodeksie cywilnym dotyczących wskazania lokali dla osób z niepełnosprawnością i wymogów, jakie muszą spełniać w uchwałach podejmowanych przez gminy.

16. Dokonanie zmian dotyczących uregulowania wsparcia osób z niepełnosprawnościami-słuchaczy studiów podyplomowych i uregulowanie prawa pobierania przez niepełnosprawnych studentów stypendium specjalnego na drugim kierunku studiów, jeżeli nie byli uprawnieni do ich pobierania w trakcie studiów na pierwszym kierunku.

Analizując propozycje zmian, warto zwrócić uwagę na działania podejmowane przez Rzecznika Praw Obywatelskich [www.rpo.gov.pl, dostęp: 4.02.2017], które mają na celu wprowadzenie zmian do polskiego ustawodawstwa, ale także na wątpliwości, które ma Rzecznik Praw Obywatelskich w związku z brakiem 
skutecznych mechanizmów prawnych gwarantujących osobom z niepełnosprawnością realizację ich uprawnień określonych w przepisach prawa.

Z dokumentu Informacja o działalności Rzecznika Praw Obywatelskich w roku 2015 oraz o stanie przestrzegania wolności i praw człowieka i obywatela, wynika, że były to następujące sprawy:

- sytuacja osób z niepełnosprawnością intelektualną lub psychiczną przebywających w jednostkach penitencjarnych i potrzeba dostosowania tych jednostek (infrastruktury, systemu kontroli, ewakuacji, przewozu samochodami służby więziennej i inne) do potrzeb osadzonych lub tymczasowo aresztowanych osób z niepełnosprawnością;

- sytuacja osób z niepełnosprawnością ruchową zatrzymanych przez Policję w jej pomieszczeniach i potrzeba dostosowania celi/pokoju dla osób poruszających się na wózku lub posiadających inne ograniczenia w poruszaniu się;

- sytuacja związana z utrudnionym dostępem osób z niepełnosprawnością do lekarzy specjalistów i do świadczeń zdrowotnych na każdym etapie: konsultacji, diagnozy, przeprowadzenia zabiegów i operacji, rehabilitacji; deficyt opieki senioralnej i deficyt świadczeń pielęgnacyjnych i opiekuńczych;

- sytuacja dotycząca dostosowania lokali wyborczych do potrzeb osób z niepełnosprawnościami;

- sytuacja dotyczy zapewnienia przez wprowadzenie skutecznych mechanizmów prawnych zagwarantowanego w ustawie o rehabilitacji zawodowej i społecznej oraz zatrudnianiu osób niepełnosprawnych możliwości dostępu do obiektów użyteczności publicznej i środków transportu osób niewidomych z psem przewodnikiem;

- potrzeba zapewnienia prawidłowego funkcjonowania przez państwo form wsparcia osób z niepełnosprawnością przewidzianych przez ustawę o rehabilitacji zawodowej i społecznej oraz zatrudnianiu osób niepełnosprawnych, urealnienie algorytmu finansowania warsztatów terapii zajęciowej, zwiększenie efektywności ich działania;

- problem dostosowania stron internetowych instytucji publicznych do potrzeb osób z niepełnosprawnościami i zapewnienie im dostępu do informacji o działalności instytucji publicznych i osób pełniących funkcje publiczne, a tym samym przeciwdziałanie ich cyfrowemu wykluczeniu;

- praktyka stosowania przepisów ustawy o języku migowym, zapewnienie dostępności usług tłumaczeniowych dla osób głuchych i głuchoniewidomych we wszystkich instytucjach publicznych, w szczególności w podmiotach leczniczych i regulacja kwestii refundacji kosztów tłumacza ze środków podmiotu zobowiązanego, przeznaczonych na ten cel;

- sytuacja związana z występującymi barierami architektonicznymi i komunikacyjnymi oraz społecznymi występującymi w dostępie osób z niepełnosprawnościami do nauki na uczelniach wyższych; 
- zapewnienie prawidłowego wykonywania orzeczeń sądów rodzinnych dotyczących umieszczania dzieci niepełnosprawnych $w$ instytucjach pieczy zastępczej oraz właściwej kontroli wojewodów nad realizacją tych zadań przez powiaty.

Na straży ochrony prawa dzieci, w tym dzieci z różnymi niepełnosprawnościami, stoi Rzecznik Praw Dziecka, który podejmuje działania kontrolne i wyjaśniające, występuje z propozycją zmian przepisów, działa w celu ochrony prawa dzieci, zapewnienia im harmonijnego rozwoju z poszanowaniem podmiotowości dzieci. Szczególną troską i pomocą otacza dzieci niepełnosprawne. W 2015 r. Rzecznik Praw Dziecka [www.brpd.gov.pl, dostęp: 10.02.2017] kierował wystąpienia do odpowiednich organów i instytucji państwowych dotyczące wielu spraw; część z nich bezpośrednio dotyczyło realizacji praw dzieci z niepełnosprawnością, pozostałe w sposób pośredni związane były z przestrzeganiem praw dzieci, $\mathrm{w}$ tym dzieci z różnymi niepełnosprawnościami.

Z dokumentu Informacja o dziatalności Rzecznika Praw Dziecka za rok 2015 oraz uwagi o stanie przestrzegania praw dziecka wynika, że w 2015 r. Rzecznik Praw Dziecka podejmował następujące sprawy dotyczące bezpośrednio praw dzieci z niepełnosprawnością:

- zapewnienie dostępności optymalnego leczenia dla dzieci cierpiących na stwardnienie guzowate, $\mathrm{w}$ przebiegu którego rozwinęły się guzy mózgu SEGA;

- zapewnienie opieki pozaszpitalnej dzieciom z zaburzeniami psychicznymi i zaburzeniami zachowania, wymagających stosowania specjalnych metod wychowawczych, terapii, a także leczenia ambulatoryjnego;

- zapewnienie dostępności specjalistycznych usług opiekuńczych dla dzieci z zaburzeniami całościowymi ze spektrum autyzmu;

- zapewnienie pomocy medycznej, dostępu do specjalistów, do zabiegów rehabilitacyjnych i sprzętu rehabilitacyjnego dzieci z niepełnosprawnościami;

- podjęcie działań dotyczących realizacji prawa dziecka do wychowania w rodzinie;

- zapewnienie uzyskania orzeczenia powiatowego zespołu do spraw orzekania o niepełnosprawności i o stopniu niepełnosprawności uprawniającego do przyznania świadczenia pielęgnacyjnego;

- podjęcie działań naprawczych zapewniających dowóz dzieci z niepełnosprawnością do szkół (wybranych przez rodziców);

- dostosowanie do znowelizowanych przepisów orzeczeń sądów w sprawie umieszczania dzieci w pieczy zastępczej;

- ujednolicenie zasad kwalifikowania przez poradnie psychologiczno-pedagogiczne ośrodkowego zaburzenia słuchu jako niepełnosprawności dającej podstawę do wydania orzeczenia o potrzebie kształcenia specjalnego; 
- usprawnienie procesu wydawania orzeczeń przez poradnie psychologiczno-pedagogiczne;

- precyzyjne kierowanie środków finansowych z subwencji oświatowej na dzieci ze specjalnymi potrzebami edukacyjnymi;

- wspomaganie szkół i nauczycieli w zakresie podnoszenia jakości kształcenia uczniów z niepełnosprawnością;

- zapewnienie równego traktowania dzieci w placówkach opiekuńczo-wychowawczych;

- ograniczanie/usunięcie nieprawidłowości dotyczących pobytu dzieci przewlekle chorych w różnych placówkach;

- zapewnienie realizacji prawa dzieci z niepełnosprawnościami do wypoczynku;

- zapewnienie dostępu dzieci z niepełnosprawnościami do nowych technologii i do dóbr kultury (do muzeów, bibliotek);

- zrealizowanie obowiązku udogodnień $\mathrm{w}$ programach telewizyjnych przez zwiększenie czasu emisji audycji telewizyjnych dla dzieci z uszkodzonym narządem słuchu lub narządem wzroku;

- zapewnienie ochrony dzieci z niepełnosprawnościami przed przemocą w środowisku domowym i poza domem;

- zapewnienie prawa dzieci z niepełnosprawnościami do godziwych warunków życia.

\section{Zakończenie}

Podkreślić należy, że w przeprowadzeniu zmian sprzyjających ochronie praw osób z niepełnosprawnościami potrzebne jest zarówno działanie podmiotów publicznych, takich jak specjalne ciała międzynarodowe czy rzecznicy krajowi, jak i organizacji pozarządowych, specjalizujących się w działaniach na rzecz przestrzegania praw człowieka. Szczególną rolę odgrywają Rzecznik Praw Obywatelskich i Rzecznik Praw Dziecka oraz organizacje pozarządowe podejmujące wysiłki na rzecz zmian systemowych, zmian legislacyjnych oraz działania ułatwiające korzystanie z instrumentów prawa międzynarodowego i krajowego, świadcząc profesjonalną pomoc osobom z niepełnosprawnościami i grupom niepełnosprawnych, których prawa są naruszane.

Obok rozwiązań legislacyjnych ważne są także działania instytucji wymiaru sprawiedliwości, organów państwowych i administracji samorządowej a także ustrój i sprawność organizacyjna instytucji pomocowych działających na rzecz osób z niepełnosprawnością. Nie bez znaczenia jest też stosunek i postawy wobec osób z niepełnosprawnościami, ich autonomii i podmiotowości a także rzeczywista akceptacja ich praw ze strony społeczeństwa. 


\section{Bibliografia}

Andrzejewski M. (1999), Prawna ochrona rodziny, Wydawnictwa Szkolne i Pedagogiczne, Warszawa.

Piasecki M., Stępniak M. (red.), (2002), Osoby z niepetnosprawnościq w polityce Organizacji Narodów Zjednoczonych, Fundacja Fuga Mundi, Lublin.

Pudzianowska D. (red.), (2014), Prawa osób z niepetnosprawnościq intelektualną lub psychiczna $w$ świetle międzynarodowych instrumentów ochrony praw człowieka, LEX Wolters Kluwer business, Warszawa.

Rybski P. (2014), Zdolność w sferze prawa osób z niepetnosprawnościami intelektualnymi oraz osób z problemami zdrowia psychicznego. Raport Agencji Praw Podstawowych Unii Europejskiej z 2013 roku /89 [w:] Prawa osób z niepetnosprawnościq intelektualna lub psychiczna w świetle międzynarodowych instrumentów ochrony praw człowieka, D. Pudzianowska (red.), LEX Wolters Kluwer business, Warszawa.

Zima M. (2010), Ubezwtasnowolnienie osób z niepetnosprawnościa intelektualna w świetle Konstytucji RP oraz Konwencji o prawach osób niepetnosprawnych [w:] Studium nad potrzebą ratyfikacji przez Rzeczpospolitą Polską Konwencji o prawach osób niepetnosprawnych, Łódź.

Zima-Parjaszewska M. (2012), Równość osób z niepetnosprawnościami wobec prawa - sytuacja prawna osób ubezwtasnowolnionych [w:] Najważniejsze wyzwania po ratyfikacji przez Polskę Konwencji ONZ o prawach osób niepetnosprawnych, A. Błaszczak (red.), „Biuletyn Rzecznika Praw Obywatelskich Źródła", nr 10.

Zima-Parjaszewska M. (2013), Artykuł 12 Konwencji o prawach osób z niepetnosprawnościami a ubezwtasnowolnienie w Polsce, „Studia Prawnicze” z. 2, s. 79-102.

Zima-Parjaszewska M. (2014), Artykuł 12 Konwencji o prawach osób z niepetnosprawnościami a ubezwłasnowolnienie w Polsce [w:] Prawa osób z niepetnosprawnością intelektualnq lub psychiczna w świetle międzynarodowych instrumentów ochrony praw człowieka, D. Pudzianowska (red.), Warszawa (przedruk).

\section{Dokumenty}

Informacja o działalności Rzecznika Praw Obywatelskich w roku 2015 oraz o stanie przestrzegania wolności i praw człowieka i obywatela, Warszawa 2016 [www.rpo.gov.pl]

Informacja o działalności Rzecznika Praw Dziecka za 2015 rok oraz uwagi o stanie przestrzegania praw dziecka, Warszawa 2016 [www.brpd.gov.pl].

Jankowska M. Prawa osób z niepetnosprawnościq intelektualna w międzynarodowych aktach prawnych [www.pfron.org.pl/download/5/78/03.Jankowska.pdf].

Konwencja o prawach osób niepetnosprawnych (Dz. U. z 25.10.2012 r., poz. 1169).

\section{Netografia}

www.pfron.org.pl

www.otk.trybunal.gov.pl/orzeczenia/otk.htm

www.ffm.pl/index.php? $\bmod =4 \& p=1 \& s r w=1 \&$ text $=159-9 \_14$

www.niepełnosprawni.gov.pl/

www.ms.gov.pl/pl/prawa-człowieka

www.niepelnosprawni.pl. 